\title{
CONTROL ORDERS POST 9-11 AND HUMAN RIGHTS IN THE UNITED KINGDOM, AUSTRALIA AND CANADA: A KAFKAESQUE DILEMMA?
}

\author{
SASCHA-DOMINIK BACHMANN*
}

\section{MATTHEW BURT ${ }^{* *}$}

This article aims to assess the impact that the European Convention of Human Rights, incorporated into British law through the Human Rights Act 1998, has had on the control order regime in the United Kingdom. It will discuss recent British jurisprudence on the topical question of whether there can be a true balance between the civil liberties of an individual and the need to protect state and society from a continuing terrorist threat. The article compares the UK's present control order system of summer 2010 with similar legislation, which the Commonwealth jurisdictions of Australia and Canada have enacted to protect their nations from the threat of terrorism. It will conclude with a discussion of possible reforms as well as other security measures which have been identified as alternatives to control orders and which form the basis of present UK governmental initiatives to limit the scope and impact of anti terrorism legislation.

\section{INTRODUCTION}

No free man shall be taken, or imprisoned, or dispossessed, or outlawed, or exiled, or in any way destroyed nor will we go upon him, nor will we send

\footnotetext{
* Senior Lecturer in Law; Assessor Jur, LLM, LLD; Sascha-Dominik teaches international law at the School of Law, University of Portsmouth and is a visiting lecturer at City University, London.

** LLB (Hons). Matthew is preparing at present for a public sector career.
} 
against him except by the lawful judgement of his peers or by the law of the land. ${ }^{1}$

The real threat to the life of the nation, in the sense of a people living in accordance with its traditional laws and political values, comes not from terrorism but from laws such as these. That is the true measure of what terrorism may achieve. ${ }^{2}$

The terrorist attacks of 11 September 2001 in the United States ${ }^{3}$ and the bombings of 7 July 2005 in London ${ }^{4}$ led to the enactment of anti-terrorism legislation in the United Kingdom (UK) and many other states as a direct consequence. The threat of terrorism is not new to the UK: last century's Irish Republican Army's resort to terrorism serves as an early example of the use of asymmetric warfare ${ }^{5}$ as a means of achieving political goals. However, the present international terrorism threat to the UK (and its strategic allies) has changed in its scope, nature and modus operandi: ${ }^{6}$ today's new challenge is the appearance of European 'home-grown' terrorism. ${ }^{7}$ The foiled Heathrow bomb plot of 2006 and the 2009 terrorist plot of the so called 'Bradford Easter

\footnotetext{
${ }^{1}$ Magna Carta 1215 (UK) [39] and 1297 (UK) [29]. The Charter of 1215 was one of the first legal instruments that stated the superiority of the ordinary law over the arbitrary justice, which was asserted by King John of England throughout his reign from 1199 to 1216 . Clause 39 (29 of the 1297 version) was thought to have been demanded as the King had increasingly enforced his will by military means rather than civilian processes. The 1297 version can be accessed at < http://www.statutelaw.gov.uk/Home.aspx >

${ }^{2}$ Lord Hoffmann in A $v$ Secretary of State for the Home Department; $X v$ Secretary of State for the Home Department [2004] UKHL 56 (16 December 2004) [97].

${ }^{3}$ Referring to the attack on the World Trade Centre and the Pentagon by Arab terrorists of the Al-Qaeda network, which took place on 11 September 2001, in which some 3000 people lost their lives. See Dominic McGoldrick, From '9-11' to the 'Iraq War 2003': International Law in an Age of Complexity (Hart Publishing, 2004) 9-11. See also National Commission on Terrorist Attacks upon the United States, The 9/11 Commission Report, Final Report (2004).

${ }^{4}$ See Home Office, Report of the Official Account of the Bombings in London on $7^{\text {th }}$ July 2005, House of Commons Paper No 1087, Session 2005-06 (2006) which recounts how 56 people died when four suicide bombers detonated explosive devices at different locations in London. Three of the bombers were born in the United Kingdom, but all four were inspired by AlQaeda.

${ }^{5}$ Home Office, Pursue, Prevent, Protect, Prepare: The United Kingdom's Strategy for Countering International Terrorism, Cm 7833 (2010) 22.

${ }^{6}$ Ibid.

${ }^{7}$ See Clive Walker, 'Know Thine Enemy as Thyself: Discerning Friend from Foe under AntiTerrorism laws' (2008) 32(1) Melbourne University Law Review 275 which states that recent terrorist attacks have come from individuals who are either second generation British citizens or individuals who have resided in the UK for most of their lives. Hence the term 'neighbour' terrorist used by Walker in his article which underlines the difference between these terrorists and the IRA terrorists of the 'troubles'.
} 
bombers' to attack UK shopping centres serve as a grim reminder of this continuing threat to a democratic and pluralistic society. ${ }^{8}$

Since 2000, the UK has enacted five major pieces of Anti-Terrorism Legislation (ATL) ${ }^{9}$ : the Terrorism Act 2000; the Anti-terrorism, Crime and Security Act 2001; the Prevention of Terrorism Act 2005; the Terrorism Act 2006 and more recently the Counter-Terrorism Act 2008. As could be expected, these anti-terrorism laws have been fiercely and extensively debated, ${ }^{10}$ the debate focusing on an apparent conflict arising from the need to protect human rights while fighting terrorism at the same time, ${ }^{11}$ as highlighted by Lord Hoffmann in his above cited pronouncement.

For the British public the legislation also puts to the test an 800 year old core principle of the common law on personal liberty, as established under the Magna Carta of 1215. One of the more controversial aspects of ATL was the introduction of control orders ${ }^{12}$ under the Prevention of Terrorism Act 2005 (PTA). Control orders are designed to restrict or prevent an individual's suspicious activities with a view to countering the threat of terrorism in general. ${ }^{13}$ The rationale and the very nature of such orders — which are mostly intended to be pre-emptive or preventative of terrorist crime - often raise the question of their overall compatibility with human rights and civil liberties in general ${ }^{14}$ and with article 5 of the European Convention on Human

\footnotetext{
${ }^{8}$ See Haroon Siddique, Bomb Plot Targeted Seven Heathrow Flights, Court Told (3 April 2008) Guardian.co.uk <http://www.guardian.co.uk/uk/2008/apr/03/plane.plot> and Duncan Gardham, Al-Qaeda Terror Plot to Bomb Easter Shoppers (9 April 2009) Telegraph.co.uk $<$ http://www.telegraph.co.uk/news/uknews/law-and-order/5133535/Al-Qaeda-terror-plot-tobomb-Easter-shoppers.html>: 'An al-Qaeda cell was days away from carrying out an "Easter spectacular" of co-ordinated suicide bomb attacks on shopping centres in Manchester, police believe'.

${ }^{9}$ The term ATL refers to all types of legislation passed with the aim of fighting terrorism, and reflects the historically changing nature and 'landscape' of terrorism.

${ }^{10}$ Clive Walker, 'Clamping Down on Terrorism in the United Kingdom' (2006) 4(5), Journal of International Criminal Justice 1144.

${ }^{11}$ Adam Sandell, 'Liberty, Fairness and the UK Control Order Cases: Two Steps Forward, Two Steps Back' (2008) 1 European Human Rights Law Review 120.

${ }^{12}$ See Steve Foster, 'Control Orders, Human Rights and the House of Lords' (2007) 12(2) Coventry Law Journal 21.

${ }^{13}$ Explanatory Notes, Prevention of Terrorism Act 2005 (UK) [4].

${ }^{14}$ Debate has also centred on? the compatibility of control orders with art 6 of the ECHR, the judicial process under which a control order is confirmed and also the right to disclosure of evidence. See Secretary of State for the Home Department $v$ MB [2007] UKHL 46 and Secretary of State for the Home Department v AF [2009] UKHL 28.
} 
Rights (ECHR) in particular. ${ }^{15}$ The new Tory-Liberal government criticised former Prime Minister Gordon Brown's anti-terrorism legislation on many occasions before coming to power. ${ }^{16}$ It remains to be seen whether some of the stricter ATL measures will now be abolished or at least amended.

In the light of such a prospect, it is time to take stock of the present (2010) ATL. This article will provide a reflective analysis of judicial challenges to the control order regime in the UK by assessing their compatibility with article 5 of the ECHR. It will compare the UK position with the situation in Australia and Canada. Finally, other possible and workable alternatives (including reforms) to the system of control orders will be examined. This article is aimed at the interested Australian reader who might have taken an interest in the Australian debate about the establishment of an independent reviewer of terrorism laws in Australia and who would like to learn more about the UK situation as a comparison.

\section{CONTROL ORDERS UNDER UK ANTI-TERRORISM LEGISLATION}

\section{A UK Anti-Terrorism Legislation post 2000}

The first comprehensive piece of anti-terrorism legislation passed in the UK was the Terrorism Act 2000 (TA 2000). The TA 2000 consolidated and reformed previous $\mathrm{ATL}^{17}$ by formulating a comprehensive set of codes to replace the hastily drafted and fragmented laws that were seen in the UK prior to the TA 2000's implementation. ${ }^{18}$ Next, and as a response to the attacks of 11 September 2001, and to the United Nations Security Council Resolution

${ }^{15}$ European Convention for the Protection of Human Rights and Fundamental Freedoms, opened for signature 4 November 1950, 213 UNTS 221 (entered into force 3 September 1953). Article 5(1) of the ECHR stipulates that everyone has the right to liberty and security of the person. No one shall be deprived of their liberty except in the circumstances listed from (a) to (e) in paragraph 1.

16 See, eg, BBC News, New Terror Law Comes into Force (13 April 2006) $<$ http://news.bbc.co.uk/1/hi/uk_politics/4905304.stm>; BBC News, Review All AntiTerrorism Laws, Say MPs (25 March 2010) <http://news.bbc.co. uk/1/hi/uk_politics/ 8583643.stm>; Number10.gov.uk, Queen's Speech - Freedom (Great Repeal) Bill (25 May 2010) <http://www.number10.gov.uk/queens-speech/2010/05/queens-speech-freedom-greatrepeal-bill-50647>.

${ }^{17}$ B Brandon, 'Terrorism, Human Rights and the Rule of Law: 120 Years of the UK's Legal Response to Terrorism' (2004) Criminal Law Review 981.

${ }^{18}$ Clive Walker, Blackstone's Guide to the Anti-Terrorism Legislation (Oxford University Press, $2^{\text {nd }}$ ed, 2009) 23. 
$1368^{19}$, the UK government passed the Anti-terrorism, Crime and Security Act 2001 (ATCSA). A major difference between it and the TA 2000 was the inclusion of a derogation clause which covered cases of non-compliance with article 5 of the ECHR. ${ }^{20}$ The derogation was made under article 15 of the ECHR (section 14 of the UK Human Rights Act, which implements the ECHR) which allows all Member States to derogate from their obligations under the Convention in times of public emergency threatening the life of the nation. The ATCSA was a legislative reflection of the findings of the European Court of Justice in Chahal $v$ United Kingdom (1996). ${ }^{21}$ There the UK was informed of the possible implications of the deportation of a terrorist suspect to a state where torture was a possibility, namely that the deportation might constitute a contravention of the strict torture prohibition of article 3 of the ECHR.

Part 4 of the ATCSA allows for the detention of terrorist suspects as well as for the deportation of foreign nationals, its powers thus falling within the wider ambit of immigration asylum police powers. ${ }^{22}$ These powers have hardly been used, with only a total of sixteen detention orders having been issued. ${ }^{23}$ Part 4 has been widely criticised as allowing a de facto detention without trial and the legality of the human rights derogation has been questioned in the light of article 15 of the ECHR (section 14 HRA): a damning report in $2003^{24}$ by a review committee of Privy Counsellors, chaired by Lord Newton, found that Part 4 was not a 'sustainable way of

${ }^{19}$ SC Res 1368 UN SCOR, 56 ${ }^{\text {th }}$ sess, 4370 mtg, UN Doc S/RES/1368 (12 September 2001) which urged the international community to redouble its efforts to prevent and suppress terrorist acts.

${ }^{20}$ See Steve Foster, 'The Fight against Terrorism, Detention without Trial and Human Rights' (2009) 14(1) Coventry Law Journal 4. Section 1(2) Human Rights Act 1998 (UK) c 42 also allows the government to avoid giving effect to the Convention to the extent that it has lodged a derogation within the meaning of s 14 of the Human Rights Act 1998.

${ }^{21}$ Chahal $v$ United Kingdom [1996] 23 EHRR 413.

${ }^{22}$ The ATCSA did not allow for the possibility of deportation, reflecting on the earlier ECHR decision in Chahal. It only allowed for the detention of foreign nationals. Foreign nationals were previously deported under separate immigration powers (Immigration Act 1971). See Walker, above n 18, 213.

23 BBC News, UK Urged to Review Terrorism Laws (27 November 2004) $<$ http://news.bbc.co.uk/1/hi/uk/4047207.stm>. There seems to be some ambiguity with this number. Walker, above n 18, 213 states the number as seventeen. However Sangeeta Shah, 'The UK's Anti-Terror Legislation and the House of Lords: The First Skirmish' (2005) 5(2) Human Rights Law Review 403, 406 states that only 16 individuals were actually detained under the ATCSA, with one certified individual detained following a conviction for fraudulent activities.

${ }^{24}$ The Anti-terrorism, Crime and Security Act 2001 (UK) c 24, s 122, allowed the Secretary of State to appoint a committee to review the Act. 
addressing the problem of terrorist suspects in the United Kingdom', ${ }^{25}$ and called for its urgent repeal. ${ }^{26}$ This call was, however, dismissed by the Home Office $^{27}$ and consequently led to no executive repeal.

The House of Lords judgment in A $v$ Secretary of State for the Home Department (A) ${ }^{28}$ forced the government to withdraw an earlier derogation clause in order to avoid a possible violation of articles 5 and 14 of the ECHR. ${ }^{29}$ The House of Lords held (Lord Hoffmann dissenting) that, in the circumstances of that case, an 'emergency threatening the life of the nation, ${ }^{30}$ existed sufficiently to warrant a derogation notice under article 15 . It consequently dismissed the appellants' first grounds of appeal. ${ }^{31}$ However, the Lords concluded that the measures implemented under Part 4 of the ATCSA (essentially detention without trial) were not proportionate, and therefore not 'strictly required by the exigencies of the situation'. ${ }^{32}$ Their Lordships also upheld the appellant's argument that the section 23 provisions were discriminatory and therefore incompatible with article 14 of the ECHR, which provides that Convention rights should be enjoyed without discrimination. ${ }^{33}$ The Lords stated that the statutory provisions allowed for foreign nationals unlike UK nationals - to be deprived of their liberty, ${ }^{34}$ this amounting to discrimination based on the appellants' nationality and immigration status.

Any potential for derogation from the HRA/ECHR under the Human Rights Act 1998 (Designated Derogation) Order 2001 came to an end when section 23 of the ATCSA was repealed ${ }^{35}$ as being incompatible with articles 5 and 14

\footnotetext{
${ }^{25}$ Privy Counsellor Review Committee, Anti-terrorism, Crime and Security Act 2001 Review: Report, House of Commons Paper No 100, Session 2003-04, 2003, 5.

${ }^{26}$ Ibid.

27 See Home Office, Counter-Terrorism Powers, Cm 6147 (2004) which details the government's response to the findings of the Privy Counsellor Review Committee on Part 4 and gives its reasons on why the government thought the ATCSA was sufficient at the time.

${ }^{28}$ Above n 2 [96].

${ }^{29}$ Ibid [47]. The UK did not actually derogate from art 14; it only derogated from art 5, and the appellants had raised an argument for a possible infringement of their art 14 right.

${ }^{30}$ As required under art 15 ECHR and Human Rights Act 1998 (UK) c 42.

${ }^{31}$ Home Office, above n 27, [29].

${ }^{32}$ Ibid 35.

${ }^{33}$ Ibid 73.

${ }^{34}$ Ibid 138.

${ }^{35}$ Parliament of United Kingdom, Human Rights Act 1998 (Designated Derogation) Order 2001, 3644, 11 November 2010. The derogation order allowed the government to derogate from art 5 of the ECHR, thus allowing Part 4 of the ATCSA to be compliant with the Human Rights Act 1998 (UK) с 42.
} 
of the ECHR as found in $A$, and was replaced with the new regime of control orders under the Prevention of Terrorism Act 2005.

\section{B Control Orders as the New Tool for Fighting Terrorism}

The Prevention of Terrorism Act 2005 (PTA) came into force on 11 March 2005, immediately causing intense criticism and debate between government and opposition parties, ${ }^{36}$ as well as in the House of Lords. ${ }^{37}$ The PTA was passed primarily to replace Part 4 of the ATCSA with the aim of allowing the executive to maintain further 'control' of individuals suspected of terrorism.

Under the PTA a control order is 'an order against an individual that imposes obligations on him for purposes connected with protecting members of the public from a risk of terrorism', 38 protection that is deemed 'necessary for purposes connected with preventing or restricting involvement by that individual in terrorism-related activity'. ${ }^{39}$ The scope of these restrictions for the controlee is quite wide ${ }^{40}$ and the restrictions can be used in combination with each other, with many controlees having multiple restrictions placed upon them. ${ }^{41}$

The PTA allows essentially for two types of control order, namely derogating and non-derogating orders. A derogating control order is one that imposes obligations on the controlee which are 'so draconian in their intrusion into liberty ${ }^{42}$ that they can be justified only by means of explicit reference to a derogation notice ${ }^{43}$ under article 15 of the ECHR. Derogating control orders

\footnotetext{
${ }^{36}$ Walker, above n 18, 214.

${ }^{37}$ Ibid. It did not help the discussion that the PTA became law just seventeen days after it had been brought before Parliament as a bill.

${ }^{38}$ Prevention of Terrorism Act 2005 (UK) с 2, s 1(1).

${ }^{39}$ Ibid 1(3).

40 These include the following restrictions: s 1(4)(d) - a restriction on association and communication with specified persons or with other persons generally; s 1(4)(f) - a prohibition on the controlee being at specified places or within a specified area at specific times or specific days; s 1(4)(j) - a requirement that the controlee give access to specific persons to their place of residence, and; s $1(4)(\mathrm{k})$ - a requirement that the persons be allowed to search the premises in order to ascertain whether obligations under the order are about to be contravened.

${ }^{41}$ Lord Carlile, Fourth Report of the Independent Reviewer pursuant to Section 14(3) of the Prevention of Terrorism Act 2005 (3 February 2009) (Home Office, London, 2009), Annex 1.

${ }^{42}$ Walker, above n 18, 222.

43 The issuance of non-derogating orders must be affirmed by a notice of derogation under art 15, and a designation order under s 14(1)(b) of the Human Rights Act 1998 (UK) c 42.
} 
are usually applied for when 'house arrest' is sought. Consequently, such orders can only be issued by a court on application by the Home Secretary under section 4 of the PTA. ${ }^{44}$ Derogating orders last for six months, ${ }^{45}$ and are renewable if the derogation notice remains in force ${ }^{46}$ Considering these legal implications, it does not surprise that the government to date has not applied for derogating control orders. ${ }^{47}$

The alternative is the issuance of a so called 'non-derogating' control order, which is issued by the Home Secretary with the confirmation of a court under sections 2 and 3 of the PTA. A non-derogating order must not, however, deprive a controlee of liberty pursuant to the terms of article 5 of the ECHR, ${ }^{48}$ thus excluding any such measures as permanent detention at a single address.

Under section 2(1) of the PTA, the Home Secretary can make a nonderogating control order if he or she has 'reasonable grounds for suspecting that the individual is or has been involved in terrorism-related activity'; ${ }^{49}$ or he or she 'considers that it is necessary, for purposes connected with protecting members of the public from a risk of terrorism, to make a control order imposing obligations on that individual' ${ }^{50}$ Non-derogating control orders expire after twelve months, with the option of renewal by the Home Secretary under section 2(4) of the PTA. In case of a renewal of the order, there is no automatic referral to a full judicial review, but the individual concerned can apply to the court for a further judicial review. ${ }^{51}$ On renewal of the order under section 2(6), the Home Secretary has to state that the order would protect the public from the risk of terrorism, and must justify the obligations imposed by the renewed order. However, there is no mandatory review requirement that evidence be adduced that the individual has actually been involved in any terrorism-related activity.

\footnotetext{
${ }^{44}$ Under s 4(1)(a) of the PTA the court must hold an immediate preliminary hearing on an application from the Secretary of State to decide whether to make a derogating control order against an individual. No time limit is, however, mentioned in the Act and the word 'immediate' is not defined within it.

${ }^{45}$ Ibid 4(8).

${ }^{46}$ Under s 6 of the PTA the Home Secretary has the power, if necessary, to impose derogating obligations under the original derogation.

${ }^{47}$ Carlile, above n 41, 15.

${ }^{48}$ Ibid s 1(2)(a).

${ }^{49}$ Prevention of Terrorism Act 2005 (UK) c 2, s 2(1)(a).

${ }^{50}$ Ibid s 2(1)(b).

${ }^{51}$ Explanatory Notes, Prevention of Terrorism Act 2005 (UK) [11].
} 


\section{Judicial Challenges to the Control Order REGIME IN THE CONTEXT OF POSSIBLE INFRINGEMENTS OF ARTICLE 5 ECHR}

Control orders are intrusive in their nature and possibly traumatic for the person affected. In a democracy they should be used only as an ultimo ratio of any anti-terror policing. The UK Joint Committee on Human Rights ${ }^{52}$ considers the control order regime per se as constituting a violation of the fundamental human right to liberty under article 5 ECHR. $^{53}$ A certain reluctance to use control orders seems to corroborate this. Since 2005 a total of only 45 individuals have been subjected to them ${ }^{54}$ and since 10 December 2009 only 12 individuals have been subjected to control orders - three fewer than the previous year. ${ }^{55}$

Two decisions by the House of Lords in Secretary of State for the Home Department $v J^{56}$ and Secretary of State for the Home Department $v E^{57}$ are particularly relevant when questioning the compatibility of control orders with article 5 ECHR.

\section{A The Case of $\mathrm{JJ}$ and Article 5 of the ECHR}

In $J J$ the six respondents were subject to an 18 hour curfew in designated one bedroom flats which were located in an area deliberately unfamiliar to them. ${ }^{58}$ The appellants were ordered to wear electronic tags and were confined to movements within 72 square kilometres beyond their residence, not including any area which they had previously lived. ${ }^{59}$ The controlees were not allowed to meet any unauthorised persons and their premises could be searched at any

\footnotetext{
52 The UK Joint Committee on Human Rights is a parliamentary select committee which undertakes thematic inquiries on human rights issues and reports its findings and recommendations to the House. It has become increasingly involved with human rights questions arising from the ECHR.

53 Joint Committee on Human Rights, Counter-Terrorism Policy and Human Rights (Fourteenth Report): Annual Renewal of Control Order Legislation 2009, House of Lords Paper No 37, House of Commons Paper No 282, Sessions 2008-09 (2009) [9].

${ }^{54}$ Carlile, above n 41, 17.

${ }^{55}$ Ibid.

${ }^{56}$ Secretary of State for the Home Department v JJ [2007] UKHL 45 (31 October 2007).

${ }^{57}$ Secretary of State for the Home Department $v$ E [2007] 1 AC 499 (HL).

${ }^{58}$ Secretary of State for the Home Department $v$ JJ [2006] EWCA 1141 (Civ) (1 August 2006) [20].

${ }^{59}$ Ibid.
} 
time. ${ }^{60}$ The House of Lords held, by a three to two majority (Lord Hoffmann and Lord Caswell dissenting), that the obligations imposed by the control orders deprived the respondents of their liberty and therefore breached article 5. Lord Bingham concluded that the controlees lives 'were wholly regulated by the Home Office, as a prisoner's would be', ${ }^{61}$ consequently concurring with the prior judgement of Sullivan J that the restrictions were 'the antithesis of liberty and equivalent to imprisonment' ${ }^{62}$

The scope of the right to liberty under article 5 of the $\mathrm{ECHR}^{63}$ was outlined by the European Court of Human Rights (ECtHR) in Guzzardi v Italy. ${ }^{64}$ The right

is not concerned with mere restrictions on liberty of movement... In order to determine whether someone has been 'deprived of his liberty' within the meaning of Article 5 (art. 5), the starting point must be his concrete situation and account must be taken of a whole range of criteria such as the type, duration, effects and manner of implementation of the measure in question. ${ }^{65}$

In the earlier High Court hearing of $J J$, Sullivan J relied on Guzzardi when stating that the obligations imposed by the orders were so severe that they amounted to a deprivation of liberty, contrary to article 5 of the ECHR. They amounted to more than a mere restriction of the right to freedom of movement, ${ }^{66}$ a right protected under article 2 of Protocol 4 to the ECHR, which the UK has not ratified yet. ${ }^{67}$

\footnotetext{
${ }^{60}$ See Secretary of State for the Home Department $v$ JJ [2006] EWHC 1623 (Admin) (28 June 2006), where Sullivan J sets out in Annex 1 of his judgment the full obligations imposed by the control orders.

${ }^{61}$ Secretary of State for the Home Department v JJ [2007] UKHL 45 (31 October 2007) [24].

${ }^{62}$ Secretary of State for the Home Department v JJ [2006] EWCA 1141 (Civ) (1 August 2006) [74].

${ }^{63}$ The Courts also took into account the decision in Mancini $v$ Italy (European Court of Human Rights, Chamber, Application No 44955/98, 2 August 2001) where it was held that house arrest for 24 hours a day constitutes a deprivation of liberty.

${ }^{64}$ Guzzardi v Italy (1980) 39 Eur Court HR (ser A). The case concerned a suspected mafia member who had been exiled to a $2 \frac{1}{2}$ square kilometre part of a small island off Sardinia. He was also subjected to a 9 hour curfew.

${ }^{65}$ Ibid [92].

${ }^{66}$ The Court of Appeal subsequently concurred with Sullivan $\mathrm{J}$ and upheld his findings in Secretary of State for the Home Department v JJ [2006] EWCA 1141 (Civ) (1 August 2006).

${ }^{67}$ See Ed Bates, 'Anti-terrorism Control Orders: Liberty and Security Still in the Balance' (2009) 29(1) Legal Studies 102.
} 
Lord Bingham pointed out in his judgment that there was 'no bright line' between liberty and restriction. ${ }^{68}$ The scope of Guzzardi is open to interpretation: ${ }^{69}$ Lord Hoffmann took the view that a controlee had to be actually imprisoned, or in circumstances which came very close to an actual imprisonment, for there to be a deprivation of liberty. ${ }^{70}$ Nevertheless, the majority of the Lords (with Lord Hoffmann and Lord Carswell dissenting) held that the general social isolation imposed on the controlees was, in effect, 'solitary confinement', due to the length of the curfew (18 hours) and the lack of opportunity to interact with the outside world. ${ }^{71}$ Lord Bingham stated that an analogy with detention in an open prison was apt, though the actual fate of the controlees was bleaker, since they could 'not enjoy the association with others and the access to entertainment facilities which a prisoner in an open prison would expect to enjoy'. ${ }^{72}$ The control orders were therefore quashed by the Lords, as the Secretary of State had no power to make the orders as they were clearly incompatible with article 5 of the ECHR, and the defects of the orders could not be cured by amending specific obligations. ${ }^{73}$

The case of $J J$ demonstrates how the Law Lords have seemingly taken a narrow approach to article 5. This was aptly shown in Lord Hoffmann's summation of the case when he stated that the right of liberty could be breached only by 'literal physical restraint'; ${ }^{74}$ otherwise there would be a danger that 'the law would place too great a restriction on the powers of the state to deal with serious terrorist threats to the lives of its citizens' ${ }^{75}$ Lord Hoffmann further observed that the liberty of an individual is 'too precious to be sacrificed for any other reason than to safeguard the survival of the state', which he felt was under threat from terrorism. ${ }^{76}$ Lord Brown, however, disagreed with this view and suggested that there was no general national

\footnotetext{
${ }^{68}$ Secretary of State for the Home Department v JJ [2007] UKHL 45 (31 October 2007) [17].

${ }^{69}$ See Bates, above n 67, 103.

${ }^{70}$ Secretary of State for the Home Department v JJ [2007] UKHL 45 (31 October 2007) [44]. Lord Hoffmann supported his statement by stating that the law would otherwise place too great a restriction on the powers of the state to deal with serious terrorist threats to the lives of its citizens.

${ }^{71}$ Ibid [24].

${ }^{72}$ Ibid.

${ }^{73}$ This finding is supported by the case $A v$ United Kingdom (European Court of Human Rights, Grand Chamber, Application No 3455/05, 19 February 2009) where the Strasbourg Court held that exceptions to art 5 required strict interpretation, which seems consistent with Lord Bingham's approach.

${ }^{74}$ Secretary of State for the Home Department v JJ [2007] UKHL 45 (31 October 2007) [36].

${ }^{75}$ Ibid [44].

${ }^{76}$ Ibid.
} 
emergency and that the right to liberty should be 'absolute in its terms'. Whether the country is in a general national emergency is certainly a moot point, as highlighted in the above case of $A .^{78}$

\section{B Response to JJ by the Government in Relation to Curfew Periods}

The then Home Secretary sought to rectify the situation in which $J J$ had left the government by arguing that if control orders breached article 5, then the courts should not quash the orders, but only the offending obligations, or should direct modifications to them. ${ }^{79}$ However, as stated above, the Lords in $J J$ had taken the line that the derogation orders were effectively a nullity, and could not be cured, and new orders were required. ${ }^{80} \mathrm{JJ}$ was subsequently taken by the government effectively to indicate that control orders with a 16 hour curfew, together with the restrictions applicable in $J J$, would not breach article $5 .^{81}$

Consequently, the UK government rejected the recommendation made by the Joint Committee on Human Rights that the maximum length of a curfew should not exceed 12 hours. ${ }^{82}$ The Home Office clearly does not view JJ as fundamentally undermining the viability of control orders, even though modified arrangements on restrictions entail greater expenditure on surveillance. $^{83}$

The notion that the maximum curfew length for control orders is 16 hours is derived from Lord Brown's judgment in $J J .^{84}$ Lord Brown adopted the stance

\footnotetext{
${ }^{77}$ Ibid [107].

${ }^{78}$ A $v$ Secretary of State for the Home Department; $X v$ Secretary of State for the Home Department [2004] UKHL 56 (16 December 2004).

${ }^{79}$ Walker, above n 18, 233.

${ }^{80}$ Helen Fenwick, 'Proactive Counter-Terrorist Strategies in Conflict with Human Rights' (2008) 22(3) International Review of Law, Computers and Technology 265.

${ }^{81}$ Joint Committee on Human Rights, The Government Reply to the Tenth Report from the Joint Committee on Human Rights, Cm 7368 (2008) 4.

${ }^{82}$ See Joint Committee on Human Rights, above n 53, [48]. The Committee also pointed out, in paragraph 49, that control orders which contain curfews of less than 12 hours are still capable of amounting to deprivation of liberty if the other restrictions imposed on the individual are sufficiently severe.

${ }^{83}$ Joint Committee on Human Rights, above $n 81$.

${ }^{84}$ Secretary of State for the Home Department v JJ [2007] UKHL 45 (31 October 2007). Lord Bingham and Baroness Hale did not explicitly endorse the 16 hour figure that Lord Brown stated in his judgment. Both Lord Bingham and Baroness Hale at paras 16 and 63 stated that the question of whether there was a deprivation of liberty required case-by-case analysis.
} 
that 16 hour curfew periods would not amount to deprivation of liberty, as such a regime 'restricts the suspect's liberty of movement rather than actually deprives him of his liberty'. ${ }^{85}$ His Lordship stated that this should nevertheless be the 'absolute limit'. Lord Brown expanded on his reasoning by stating that the European (Strasbourg) Court of Human Rights would surely conclude that a longer curfew regime than 16 hours a day would be a deprivation of liberty, ${ }^{86}$ and that it might conclude 16 hours to be too long. But this was for the Strasbourg Court to decide. ${ }^{87}$

The Joint Committee on Human Rights ${ }^{88}$ asserted in general that the topic of curfew periods would find its way to the Strasbourg Court in due course. It stated also that, in the meantime, Parliament should reach its own view about what the right to liberty under article 5 requires in relation to curfew periods, and should then define it in the statutory framework governing control orders. $^{89}$

Legal opinion seems to be divided on whether to confirm the view that a 16 hour curfew does not constitute a de facto deprivation of liberty in terms of article 5 ECHR. See, for example, the case of Secretary of State for the Home Department $v A E .^{90}$ The most recent case on this issue - Secretary of State for the Home Department $v A P^{91}$ — has given the Supreme Court (formerly the House of Lords) a chance to establish whether a 16 hour curfew is contrary to article 5. At first instance the High Court had held that a 16 hour curfew can effect a deprivation of liberty when it is coupled with other restrictions, to the extent that it imposes a high degree of social isolation. ${ }^{92}$ Keith $\mathrm{J}$ held that the restrictions were the 'equivalent of internal exile' which caused AP to be 'socially isolated during the relatively few hours in the day when he is not under house arrest [and unable]to make even social

They held that it was 'inappropriate to draw a sharp distinction' as regard to curfew period lengths.

${ }^{85}$ Ibid [105].

${ }^{86}$ Ibid [106].

${ }^{87}$ Ibid.

${ }^{88}$ See Joint Committee on Human Rights, above n 81, [41].

${ }^{89}$ Ibid [42].

${ }^{90}$ Secretary of State for the Home Department v AE [2008] EWHC 585 (Admin) (20 March 2008). The court however stated that a 16 hour curfew could not be automatically imposed on every controlee. It would be necessary for the court to assess the facts on each case: [84].

${ }^{91}$ Secretary of State for the Home Department v AP [2010] UKSC 24 (16 June 2010).

${ }^{92}$ Secretary of State for the Home Department v AP [2008] EWHC 2001 (Admin) (12 August 2008). The court imposed on the controlee a prohibition on pre-arranged meetings, except with near relatives, and it required that the controlee live outside London (where he and other family members lived). 
arrangements because pre-arranged meetings ... are prohibited, ${ }^{93}$ This led to Keith J concluding that the restrictions placed on AP were a deprivation of liberty rather than a restriction of movement. ${ }^{94}$

The Court of Appeal ${ }^{95}$ reversed the decision of the High Court (Carnwath LJ dissenting) and held that Keith $\mathrm{J}$ was wrong in law to permit the issue of family visits to 'tip the balance' towards a breach of article 5 ECHR, ${ }^{96}$ as it was not impossible for him to be visited by his family. ${ }^{97}$ The Supreme Court has, however, subsequently reversed the decision of the Court of Appeal and held that the 16 hour curfew period along with the restrictions placed upon AP, did amount to a deprivation of liberty.$^{98}$ Lord Brown concluded that the practical difficulties faced by the family in visiting AP should not have been ignored by the Court of Appeal and restored Keith J's original judgment. ${ }^{99}$

\section{The Case of E and the Possible Conflict with Article 5}

Similarly to JJ, the case of the Secretary of State for the Home Department $v$ $E^{100}$ focused on the question of whether control order curfew periods constitute a deprivation of liberty within the meaning of article 5 . The suspect $\mathrm{E}$ was required to reside at a particular address and remain there for a 12 hour period between $7 \mathrm{pm}$ and $7 \mathrm{am}$. E was prohibited from having unauthorised visitors to his apartment and any pre-arranged meetings elsewhere, and was prohibited from using a mobile phone or any equipment capable of connecting to the internet. ${ }^{101}$

${ }^{93}$ Ibid [97].

${ }^{94}$ Ibid. Keith J's view would have been different, however, if the controlee had remained in London, so as to allow him to visit his close relatives who lived there. Keith $J$ at [99] duly quashed the condition that the controlee had to reside in a town distant from London.

${ }^{95}$ AP $v$ Secretary of State for the Home Department [2009] EWCA 731 (Civ) (15 July 2009).

${ }^{96}$ Ibid [32].

${ }^{97}$ Ibid [31]. Keith J in Secretary of State for the Home Department v AP [2008] EWHC 2001 (Admin) (12 August 2008) [88] stated that the family of AP could visit him on Sundays and other days of the week outside the school term, and use off peak travel times to get the advantage of lower fares.

${ }^{98}$ AP $v$ Secretary of State for the Home Department [2009] EWCA 731 (Civ) (15 July 2009) [15].

${ }^{99}$ Ibid.

${ }^{100}$ Secretary of State for the Home Department v E [2007] 1 AC 499 (HL).

${ }^{101}$ See ibid [34]-[37] for a detailed list of all the obligations imposed on the suspect by the control order. 
Initially, the High Court as the court of first instance had found that the cumulative effect of the curfew period, and the other obligations imposed by the control order, deprived $\mathrm{E}$ of his liberty, therefore breaching article 5 of the ECHR. ${ }^{102}$ The High Court followed the approach of the Court of Appeal decision in $J J$, in looking at the cumulative effect of the restrictions set out in the control order. ${ }^{103}$

The Court of Appeal, however, took a different view, ${ }^{104}$ with Pill LJ stating that the starting point for a consideration on whether article 5(1) had been breached was to consider the actual physical liberty of the person ${ }^{105}$ in terms of an individual liberty in the classic sense. ${ }^{106}$ The Lord Justices found a clear distinction between the facts of $E$ and those of $J J$ and declared the cases to be very different in their facts. ${ }^{107} \mathrm{E}$ was deprived only of the right to leave his home in the overnight hours (7pm to $7 \mathrm{am})$ with no geographical restriction place upon him during the daytime. ${ }^{108}$ This led the Court of Appeal to hold that the degree of physical restraint upon the liberty of E, bearing in mind the 'type, duration, effects and manner of implementation' of the order, ${ }^{109}$ was far from constituting a deprivation of his liberty under article $5 .{ }^{110}$ The House of

102 Secretary of State for the Home Department v E [2007] EWHC 233 (Admin) (16 February 2007) [242]. The High Court also looked at other ECHR based arguments. Beatson J held that the Home Secretary was informed properly about E's mental health and the health of his family as well as the impact of the obligations on them: [269]. Beatson J also concluded that the control order restrictions did not violate or risk violating E's children's rights under art 3 of the ECHR: [309].

103 Ibid [241].

${ }^{104}$ Secretary of State for the Home Department v E \& S [2007] EWCA 459 (Civ) (17 May 2007).

${ }^{105}$ Engel $v$ The Netherlands (No 1) (1976) 1 EHRR 647, [58]. In that case the European Court of Human Rights stated: 'In proclaiming the "right to liberty", paragraph 1 of Article 5 (art 51 ) is contemplating individual liberty in its classic sense, that is to say the physical liberty of the person. Its aim is to ensure that no one should be dispossessed of this liberty in an arbitrary fashion'.

${ }^{106}$ Secretary of State for the Home Department v E \& S [2007] EWCA 459 (Civ) (17 May 2007) [52].

${ }^{107}$ Ibid [60].

${ }^{108}$ Ibid [62]. It was also his own home, where he could live with his wife and young family, in an area well known to him.

109 This is derived from Engel $v$ The Netherlands (No 1) (1976) 1 EHRR 647, [59], where the Court stated: '....account should be taken of a whole range of factors such as the nature, duration, effects and manner of execution of the penalty or measure in question' when determining the scope of art 5 ECHR.

${ }^{110}$ Engel $v$ The Netherlands (No 1) (1976) 1 EHRR 647, [69]. Also see Trijonis v Lithuania (European Court of Human Rights, Chamber, Applications No 2333/02, 15 December 2005) where the 'home arrest' also included an obligation to remain at home throughout weekends, and consequently the complaint was held inadmissible. 
Lords subsequently concurred with the Court of Appeal in its summation that there was no contravention of article $5(1) .^{111}$

\section{Some Concluding Observations on the Compatibility of Control Orders with Article 5}

In conclusion, the jurisprudence emanating from the courts shows that control order curfew periods and restrictions have to be assessed on a case by case basis to decide whether they contravene article 5 . The cases of $J J$ and $E$ clearly showed that previously courts considered curfew periods of 16 hours or less as a non deprivation of liberty within the meaning of article 5 . However, with the recent Supreme Court ruling in $A P$, the courts have now seemingly taken the stance that a 16 hour curfew coupled with other restrictions does in fact amount to a deprivation of liberty. It has yet to be seen whether the government will now impose curfew periods of no more than 16 hours in order to comply with the decisions emanating from the Supreme Court. So far the government has resisted the continued pressure applied to it by the Joint Committee on Human Rights to have the maximum curfew length set at 12 hours, arguing that if it did this, it would significantly damage its ability to protect the public from the threat of terrorism. ${ }^{112}$ Some academic commentators seem to affirm this view, considering that, for the purpose of combating terrorism, significant limitations to fundamental civil liberties may have to take place within the scope of the ECHR. ${ }^{113}$ Others point out that case law implies the opposite: the case of $E$, considered in conjunction with $J J$, indicates that the government's policy of employing non-derogating control orders is proving ineffective in security terms. ${ }^{114}$

The courts' refusal to accept curfews which confine individuals to their homes for long periods of time, as seen in $J J$ and $A P$, as being compatible with article 5 of the ECHR, puts the government in a difficult situation. If the courts will allow only limited curfews, such as the one in $E$, there might be a possibility that controlees will abscond. ${ }^{115}$ Also, limited curfew periods will still allow determined suspects to proceed with possible terrorist-related activities, thus defeating the whole rationale behind the implementation of control orders. Doubtless, courts and government will continue to disagree

\footnotetext{
111 Secretary of State for the Home Department $v$ AP [2008] EWHC 2001 (Admin) (12 August 2008) [15].

112 Joint Committee on Human Rights, above n 81.

113 Sandell, above n 11, 124.

${ }^{114}$ Fenwick, above n 80, 267.

115 Carlile, above n 41, [17]. Lord Carlile lists a total of 7 control order abscondees.
} 
over the difficult task of balancing the scope of protection granted by article 5 and the need to safeguard the security of the nation.

\section{LOOKIng Abroad - Control ORders in Australia AND CANADA}

Since the terrorist attacks of 11 September 2001 other Commonwealth countries have followed the example of the UK and introduced their own form of 'control orders' to their legislative systems. Australia and Canada are the main Commonwealth jurisdictions which have implemented legislation, which is designed to restrict or prevent an individual's movements as a means of combating terrorism and which raises questions of human rights compatibility.

\section{A The Australian Control Order Regime}

\section{Overview}

Post 9/11Australia implemented a range of anti-terrorism measures following the September 11 attacks on the United States. ${ }^{116}$ Although there has not been a terrorist attack on Australian soil itself, Australia nonetheless has been directly affected by terrorism. ${ }^{117}$ Australian citizens died in the September 11 attacks and only a year later, on 12 October 2002, 88 Australian holiday makers were killed in the Bali bombings in Indonesia. ${ }^{118}$ In the absence of any substantial experience, either of a terrorist threat or of designing a legal framework to counter it, the Commonwealth of Australia has relied heavily on the anti-terrorism laws of the UK when constructing its own national security framework. ${ }^{119}$ On 27 September 2005, and as a response to the 7 July

116 See Paul Fairall and Wendy Lacey, 'Preventative Detention and Control Orders under Federal Law: The Case for a Bill of Rights' (2007) 31(3) Melbourne University Law Review 1072, 1074 which provides a sound description of the counter-terrorism measures set out by the Australian government. Examples of legislation passed are the Security Legislation Amendment (Terrorism) Act 2002; the Criminal Code Amendment (Suppression of Terrorist Bombings) Act 2002; and the Border Security Legislation Amendment Act 2002.

${ }^{117}$ See George Williams, 'The Rule of Law and the Regulation of Terrorism in Australia and New Zealand' in Victor Ramraj, Michael Hor and Kent Roach (eds), Global Anti-Terrorism Law and Policy (Cambridge University Press, 2005) 534, for an overview.

${ }^{118}$ Ibid. The Bali bombings occurred when two bombs exploded in the Sari Club and Paddy's Bar causing the deaths of 202 people.

119 Andrew Lynch, 'Control Orders in Australia: A Further Case Study in the Migration of British Counter-Terrorism Law’ (2008) 8(2) Oxford University Commonwealth Law Journal 159. 
bombings in London, the Council of Australian Governments decided to strengthen anti-terrorism laws further by implementing [or passing?] the AntiTerrorism Act [No 2] 2005 (ATA) which amended the Criminal Code Act 1995. ${ }^{120}$ Control orders, preventative detention orders ${ }^{121}$ and prohibited contact orders ${ }^{122}$ were all introduced into the Criminal Code Act through the ATA.

Control orders under Division $104^{123}$ of the Criminal Code Act can last for periods of up to 12 months, similar to the UK control order system. The issuance of a control order involves a senior Australian Federal Police (AFP) member making a written request to the Attorney-General. ${ }^{124}$ Once consent has been given, ${ }^{125}$ the senior AFP member must then put a request before a court. ${ }^{126}$ The court must then be satisfied that, on the balance of probabilities, the order would substantially assist in preventing a terrorist act, or that the individual has provided training to, or received training from, a listed terrorist organisation. ${ }^{127}$

The Australian control order system therefore follows the example of the UK Prevention of Terrorism Act (PTA), concerned with individuals who are involved in 'terrorism related activity' which is defined in section 1 (9) of the PTA. ${ }^{128}$ Like the PTA, the amended Criminal Code Act contains in section 104.5(3) an exhaustive list of restrictions and obligations under which a

\footnotetext{
${ }^{120}$ Fairall and Lacey, above n 116, 1075.

${ }^{121}$ See Criminal Code Act 1995 (Cth) s 105.1. PDOs are designed to detain persons, suspected of some degree of involvement with terrorism, where there is insufficient evidence to justify a formal charge. PDOs can be distinguished from control orders because, unlike the PDOs, control orders stop short of imprisoning the individual in a state facility: Thomas $v$ Mowbray (2007) 233 CLR 307 [18].

${ }^{122}$ Criminal Code Act 1995 (Cth) s 105.15(1). PCOs prohibit a detained person from contacting a person named in the order while the detained person remains in preventative detention.

${ }^{123}$ Fairall and Lacey, above n 116, 1073.

${ }^{124}$ Criminal Code Act 1995 (Cth) s 104.2(1). Note however that in urgent circumstances a senior AFP member may request a control order without obtaining the Attorney-General's consent. Subdivision C of the Criminal Code Act 1995 contains the requirements for this.

${ }^{125}$ Criminal Code Act 1995 (Cth) s 104.2(2). The Senior AFP member must have reasonable grounds for either (1) considering that the order sought would 'substantially assist in preventing a terrorist act'; or (2) suspecting that the individual has provided or received training from a proscribed organisation.

${ }^{126}$ Ibid s 104.3.

${ }^{127}$ Ibid s 104.4(1)(c).

${ }^{128}$ The Prevention of Terrorism Act 2005 (UK) c 2, s 1(3) states that the obligations imposed by the control order must be considered 'necessary for the purposes connected with preventing or restricting involvement by that individual in terrorism related activity'.
} 
controlee can be placed. ${ }^{129}$ The court must, however, be satisfied on the balance of probabilities that each of the obligations, prohibitions and restrictions imposed is necessary and reasonably appropriate and adapted for the purpose of protecting the public from a terrorist attack. The statutory framework governing control orders in Australia is therefore very similar to that of the UK, with a few exceptions.

One such exception is the fact that Australian control orders are issued by the federal courts rather than a member of the executive. In the UK the Secretary of State issues the control order, which is then confirmed by the court, and the judiciary has a role only in cases where control orders are challenged. It appears, therefore, that the Australian judiciary, in its active role in issuing control orders, is likely to ensure stronger protection of an individual controlee's rights than would be the case in the UK. Some commentators see this strong role of the judiciary as problematic, blurring the distinction between the roles of the executive and the judiciary. They criticise it for effectively watering down the concept of the separation of powers. ${ }^{130}$

Another difference is the absence of an equivalent to section 8 of the PTA which provides for a legislative 'check and balance' to ensure that the Secretary of State's decision to issue a control order has been undertaken with consideration of the viability of a criminal prosecution. ${ }^{131}$ The AFP Commissioner is statutorily obliged, under section 104.19(1) of the Criminal Code Act, to apply for revocation of a control order only when satisfied that the grounds for its issuance have ceased to exist — not when evidence becomes available that might support a prosecution.

Another, significant, difference of the Australian control order regime is the absence of a mechanism for independent review of ATL in general. In the UK, under section 14(2) of the PTA, an independent reviewer of terrorism

${ }^{129}$ The restrictions include, (a) a prohibition or restriction on the person being at specific areas or places; (c) a requirement that the person remain at specific premises between specified times each day, or on specified days; (e) a prohibition or restriction on the person communicating or associating with specific individuals.

${ }^{130}$ Lynch, above $\mathrm{n} 119,183$. Lynch suggests that the judiciary should be kept out of the process by which the orders are made, and therefore should be reserved for a more clearly defined role of reviewing executive decisions.

131 The Prevention of Terrorism Act 2005 (UK) c 2, s 8(2) provides that before making or applying for a control order, the Secretary of State must consult the police to ascertain whether there is enough evidence available that could be realistically used for the purposes of prosecuting the individual for a terrorism related offence. Section 8(4) provides that the question of whether a criminal prosecution is viable is kept under review while the order persists and the police are to advise on the matter at meetings of the Control Order Review Group (CORG). See also Lynch, above n 119, 181. 
legislation must be appointed — currently Lord Carlile of Berriew. ${ }^{132}$ Despite the fact that Australia has an Inspector General of Intelligence and Security, his authority does not cover the activities of the AFP or the legislative framework which governs the Australian control order regime. ${ }^{133}$ The appointment of an independent reviewer of terrorist legislation, who would report annually to Parliament and have the ability to set his own agenda, had been recommended by the Parliamentary Joint Committee on Intelligence and Security. ${ }^{134}$ The latest bill, proposing an independent reviewer - the so called National Security Legislation Monitor — is being considered by the Australian government after some considerable debate. ${ }^{135}$ Although the proposed monitor's role is modelled on the UK's Independent Reviewer of Terrorism Laws, earlier opinions suggested that the Australian model for an independent reviewer should differ from that of the UK by having a panel of reviewers rather than a single person, in order to draw on wider expertise. ${ }^{136}$ It has also been suggested that the reviewers should have explicit links to a Parliamentary committee in order to ensure that there is constant debate on the work of the reviewer. ${ }^{137}$

\footnotetext{
${ }^{132}$ Lord Carlile, Fifth Report of the Independent Reviewer pursuant to Section 14(3) of the Prevention of Terrorism Act 2005 (1 February 2010) Official Documents <http://www. official-documents.gov.uk/document/other/9781849871518/9781849871518.pdf >. Lord Carlile also visited Australia in June 2009 to give advice on the prospect of creating a similar monitoring role in Australia.

${ }^{133}$ Bronwen Jaggers, 'Anti-terrorism Control Orders in Australia and the United Kingdom: A Comparison’ (Research Paper No 28, Parliamentary Library, Parliament of Australia, 2008) 11. Although complaints regarding the actions of the AFP may be made to the Commonwealth Ombudsman, the Ombudsman may only review individual complaints, rather than the overall operation of the control order scheme.

134 Parliamentary Joint Committee on Intelligence and Security, Parliament of Australia, Review of Security and Counter Terrorism Legislation (2006) 20. This call for an independent reviewer of terrorist legislation has also been made by Andrew Lynch in 'An Independent Reviewer for Australian Terror Laws?' (Paper Presented at Federal Criminal Law Conference, 5 September 2008).

${ }^{135}$ Law Council of Australia, Submission No 2081 to the Senate Legal and Constitional Affairs Committee, Inquiry into the Independent Reviewer of Terrorism Laws Bill 2008 (No 2), 15 September 2008. The Independent Reviewer of Terrorism Laws Bill 2008 [No 2] is a private Senators' bill co-sponsored by Senators Troeth and Humphries, introduced into the Senate on 28 June 2008. For the new post, see Andrew Lynch and Nicola McGarrity, At Last, an Independent Reviewer of Terrorism Laws (16 July 2009) Inside Story <http://inside.org.au/atlast-an-independent-reviewer-of-terrorism-laws>.

${ }^{136}$ Clive Walker, 'The United Kingdom's Anti-terrorism Laws: Lessons for Australia' in Andrew Lynch, Edwina MacDonald and George Williams (eds), Law and Liberty in the War on Terror (Federation Press, 2007) 181, 189.

${ }^{137}$ Ibid 189, referring to a possible affiliation with the Parliamentary Committee on Intelligence and Security.
} 


\section{Judicial Challenges to Control Orders in Australia}

Before turning to the judicial challenges in Australia, it is interesting from a Continental point of view to observe an overall failure by the Australian government to successfully communicate the necessity of control orders to the wider public. ${ }^{138}$ The former used the existence of the UK's control order regime as reassurance to the Australian public that control orders were 'not very extraordinary at all', and that the orders came from the legitimate arsenal of anti-terrorism measures that any liberal and democratic government would use in responding to the threat of terrorist violence. ${ }^{139}$

Australia is the only western democracy not having a written bill of rights, entrenched or otherwise, for the protection of civil and fundamental rights. ${ }^{140}$ Instead, it prefers to rely on informal mechanisms such as a trust in the basic decency of the government, an independent judiciary, the transparency of judicial and administrative processes, and trial by jury. ${ }^{141}$ Political and legal debate in Australia is also usually unconstrained by fundamental human rights principles and the rule of law. ${ }^{142}$ However, the push for an Australian bill of rights, influenced by the example of the British Human Rights Act 1998, came to an end in April 2010. In that month the Australian government rejected the recommendation of the National Human Rights Consultation Committee, chaired by Father Frank Brennan, that the Parliament ought to enact a statutory bill of rights like the HRA. Despite the fact that since 1980 Australia has been party to the International Covenant on Civil and Political Rights (ICCPR) as well as other major international human rights instruments ${ }^{143}$ it still has not enacted a domestic Human Rights Act. ${ }^{144}$ Australia has opted instead for the creation of a general Human Rights Framework which outlines

\footnotetext{
${ }^{138}$ Lynch, above n 119, 185.

${ }^{139}$ Ibid 174.

${ }^{140}$ See Fairall and Lacey, above n 116, 1095 and Tom Campbell, Jeffrey Goldsworthy and Adrienne Stone, Protecting Rights without a Bill of Rights: Institutional Performance and Reform in Australia (Ashgate Publishing Limited, 2006) 1.

${ }^{141}$ Fairall and Lacey, above n 116, 1095.

${ }^{142}$ Williams, above $\mathrm{n} 117,536$. The contrast to the UK is evident. In the UK control orders have to be compatible with the Human Rights Act 1998 (UK) c 42, which gives the ECHR effect in UK law.

${ }^{143}$ Australia is also party to the UN Convention against Torture (CAT) and the International Covenant on Economic, Social and Cultural Rights (ICESCR).

${ }^{144}$ At the state and territory level there are two examples of human rights instruments, the Human Rights Act 2004 (ACT) and the Charter of Human Rights and Responsibilities Act 2006 (Vic). See Jaggers, above n 133, 11.
} 
a series of pre-legislative measures to protect and promote human rights. ${ }^{145}$ Consequently, judicial challenges to control orders differ from UK cases by focussing on constitutional questions arising from the application of such measures.

In August 2007, the High Court of Australia upheld the constitutional validity of the new control order regime in the case Thomas $v$ Mowbray. ${ }^{146}$ The court held by a 5:2 majority (Kirby and Hayne JJ dissenting) that the validity of Division 104 was sufficiently supported by the defence power ${ }^{147}$ and did not breach Chapter Three of the Australian Constitution. ${ }^{148}$ The appellant, Thomas, argued that Division 104 was invalid because it was not supported by one or more express or implied heads of legislative power under the Commonwealth Constitution. ${ }^{149}$ Gleeson CJ quickly dismissed this claim and held that the legislation governing control orders was an exercise of the defence power under section 51(iv) of the Australian Constitution as well as of the external affairs power under section 51(xxix).

The High Court also rejected Thomas' further argument that the powers invested in the judiciary were not judicial in nature and therefore could not constitutionally be conferred on a court by Commonwealth legislation. ${ }^{150}$ Gleeson CJ's reasoning for holding that Chapter Three of the Australian Constitution was not contravened ${ }^{151}$ included analogies with powers that historically had been exercised by courts in Australia or elsewhere, such as the power to grant bail and to make apprehended violence orders. ${ }^{152}$ The High

\footnotetext{
${ }^{145}$ See Human Rights Framework, released by the Australian Government on 21 April 2010 at $<$ http://www.ag.gov.au/www/agd/agd.nsf/Page/Human_rights_and_antidiscriminationAustralia\&apos;s_Human_Rights_Framework $>$.

${ }^{146}$ Thomas $v$ Mowbray (2007) 233 CLR 307. The appellant, Jack Thomas, had his first control order issued by the Federal Magistrates Court of Australia on 27 August 2006. See Jabbour $v$ Thomas (2006) 165 A Crim R 32. For further background to the case, see Jaggers, above $\mathrm{n}$ 133, 5; DPP (Cth) $v$ Thomas (Sentence) [2006] VSC 120 (31 March 2006); and $R v$ Thomas (2006) 14 VR 475.

147 The defence power is one of the legislative powers of the Australian Parliament, governed by the Australian Constitution s 51. Under s 51(iv) the Australian Parliament has the power to enact legislation to make laws with respect to: 'the naval and military defence of the Commonwealth and of the several States'. Thomas v Mowbray (2007) 233 CLR 307 [17] and [132] provides a more comprehensive explanation of the defence power.

148 The Australian Constitution at chapter 3 concerns the judicature.

${ }^{149}$ Thomas v Mowbray (2007) 233 CLR 307 [3].

${ }^{150}$ Ibid [3].

${ }^{151}$ Ibid [30].

152 Ibid [17]. Gleeson CJ did concede, however, that neither was a perfect analogy to control orders.
} 
Court also accepted that it was more opportune for a court to exercise such powers than for other institutions to do so. ${ }^{153}$ This was due to the courts offering better protection for human rights and to the fact that 'to decide that such powers are exclusively within the province of the executive branch of government would be contrary to our legal history, ${ }^{154}$ The dissenting opinion of Kirby J, however, argued that Division 104 was beyond the judicial power of the Commonwealth, with Kirby J stating that the control order regime was 'novel and offensive to principle'. ${ }^{155}$

The decision in Thomas $v$ Mowbray was silent on the question of whether the control order restrictions placed on the appellant violated his civil liberties or affected his right of liberty. It only challenged the constitutional doctrine in Australia about the role and independence of the federal judiciary. ${ }^{156}$ To date no civil liberty arguments have been raised before the federal courts in Australia, unlike the position in the UK where possible violations of civil liberties through ATL have been intensely debated. Thomas $v$ Mowbray is to date the only significant case in Australia which has challenged the country's control order regime. The only other control order to be issued in Australia was against David Hicks in December 2007 (confirmed in February 2008). ${ }^{157}$ Although there were no constitutional challenges to the control order regime in that case, the conditions of the order were slightly altered by Federal Magistrate Donald Warren, ${ }^{158}$ which could be perceived as a small victory to Mr Hicks in reducing the regularity of his reporting to the police. ${ }^{159}$

With few control orders having been issued to date in Australia (compared with a total of 45 in the UK), mounting criticism of the regime and an apparent willingness by Australian security services to resort to monitoring and surveillance tactics instead, the question arose of whether control orders are strictly necessary in Australia at all.

\footnotetext{
153 Ibid.

${ }^{154}$ Ibid [15].

155 Ibid [357].

${ }^{156}$ Lynch, above n 119, 159.

${ }^{157}$ Jabbour v Hicks [2008] FMCA 178 (19 February 2008).

${ }^{158}$ Ibid [47]. The AFP requested that one of the restrictions of the control order should be that Mr Hicks report to the police three times per week. However, due to other methods being available to the AFP to monitor Mr Hicks's movements, Federal Magistrate Warren held that reporting to the AFP on two occasions per week was 'more reasonably appropriate'.

159 Jaggers, above n 133, 15.
} 


\section{B Controlling Terror Suspects: The Canadian Approach}

\section{Overview and Introduction to the Canadian Security Certificate regime}

Canada has taken a different approach from the UK in trying to 'control' terrorist suspects. The policy instrument of choice has been immigration legislation allowing for the deportation - by means of so-called Security Certificates - of non-citizens suspected of constituting a security threat to the country. ${ }^{160}$ Only two months after September 11 the Canadian government enacted the Immigration and Refugee Protection Act (IRPA), which received Royal Assent on 1 November 2001. ${ }^{161}$ The actual draft legislation pre-dated the 9/11 attacks on the United States, and the content of the Act itself did consequently not reflect on the attacks; its content just served to dampen previous political dissent. ${ }^{162}$ The Canadian government had already decided to take a robust approach to non-citizens; the events of September 11 simply made it easier to implement these measures and to communicate them to the broader public. ${ }^{163}$

The raison d'être for the use of a security certificate is to remove from Canada 'non-Canadians who have no legal right to be [t]here and who pose a serious threat to Canada and Canadians' ${ }^{164}$ Section 77 of the IRPA allows the issuance of a so-called security certificate, indicating that the presence of a permanent resident or foreign national is undesirable on grounds of (public) security, a possible violation of human or international rights, or allegations of involvement in? serious and organised criminality. ${ }^{165}$ After issuance of the certificate the named individual can then be indefinitely detained, pending reasonableness review of their case by the Federal Court, under section 78 of the IRPA. ${ }^{166}$

\footnotetext{
${ }^{160}$ Audrey Macklin, 'The Canadian Security Certificate Regime' (2009) March, Centre for European Policy Studies: Special Report, 1.

${ }^{161}$ Marianne Davies, 'Unequal Protection under the Law: Re Charkaoui and the Security Certificate Process under the Immigration and Refugee Protection Act' (2006) 69 Saskatchewan Law Review 375, 378.

${ }^{162}$ Macklin, above n 160, 2.

${ }^{163}$ Ibid.

164 Public Safety Canada, Security Certificates (5 June 2009) <http://www.publicsafety. gc.ca/prg/ns/seccert-eng.aspx> .

${ }^{165}$ Immigration and Refugee Protection Act, SC 2001, c 27, s 77(1).

${ }^{166}$ Ibid s 81 . The Minister and the Minister of Citizenship and Immigration may issue a warrant for the arrest and detention of a person named on a certificate if they have reasonable grounds
} 
Pursuant to section 82(2) of the IRPA, a review of the reasons for continued detention must be commenced, and, until a final determination is made concerning the reasonableness of the certificate, the individual must be brought before a judge at least once in the six month period following reach review. ${ }^{167}$ A judge can order continued detention only if he or she is satisfied that the detainee continues to be a threat either to national security or to the safety of others, or that the detainee is unlikely to appear for proceedings or removal. ${ }^{168}$ However these requirements are applicable only in cases of a permanent resident. ${ }^{169}$ If the subject is a foreign national with non-permanent residence status, ${ }^{170}$ the IPRA does not mandate any review of the detention prior to the determination of the security certificates reasonableness. ${ }^{171}$ Therefore the decision to issue such a certificate does also serve as a decision on the legality of a subsequent removal order which cannot be appealed against. ${ }^{172}$ Once the Security Certificate has been upheld as 'reasonable' by the Federal Court, the named individual is deportable with no further opportunity to appeal. Section 80 of the IRPA implies that the security certificate which has been determined as reasonable by the courts 'serves' as a removal order. The IPRA does not place a statutory limit on the length of detention, except that it allows the person named on the certificate to apply for release at any time, for the purpose of permitting departure from Canada, under section 82.4 of the Act.

These measures are very similar to Part 4 of the UK's Anti-terrorism, Crime and Security Act 2001, which authorised the detention without trial of foreign nationals. The UK could not originally deport foreign nationals, however deliberately, in cases where a possible violation of the ECHR would be the consequence. The European Court of Human Rights had held in Chahal $v$ $U K,{ }^{173}$ that an individual could not be returned to his country of origin if faced

\footnotetext{
to believe that the person is a danger to national security, or to the safety of any person, or is unlikely to appear at a proceeding, or for removal. Under s 78 of the IRPA a judge of the Federal Court will then determine whether the certificate is reasonable and will duly quash the certificate if it is not.

${ }^{167}$ Ibid s 82(1) states that a judge must commence a review of the reasons for the person's continued detention within 48 hours after the detention begins.

168 Ibid s 82(5)(a).

${ }^{169}$ Macklin, above n 160, 3.

${ }^{170}$ Immigration and Refugee Protection Act, SC 2001, c 27, s 2(1) defines a foreign national as 'a person who is not a Canadian citizen or permanent resident, and includes a stateless person'. The category includes asylum seekers, refugees who have not yet obtained permanent residence, lawful temporary residents and non-status migrants.

${ }^{171}$ Macklin, above n 160, 3.

${ }^{172}$ Immigration and Refugee Protection Act, SC 2001, c 27, s 80.

${ }^{173}$ Chahal v United Kingdom [1996] 23 EHRR 413.
} 
with the possibility of torture or any other treatment contrary to article 3 of the ECHR. This position has changed with the introduction of control orders together with so called Deportation with Assurances (DWAs) measures, whereby the Government obtains assurances from other countries which ensure that individuals can be deported there without a risk of their human rights being breached. ${ }^{174}$

Section 82.4 of the Canadian IPRA effectively detains foreign nationals suspected of terrorism offences indefinitely, unless they decide to return to their own or another country. This consequence reminds us of the stark warning of Nicholls $\mathrm{J}$ in his seminal decision in the UK case A $v$ Secretary of State for the Home Department, ${ }^{175}$ where he describes section 23 of the ATCSA as effectively creating a prison which only 'has three walls' due to the certified individuals being allowed release only if they are willing to face the 'prospect of ill treatment in any country willing to admit them'. ${ }^{176}$ The constitutionality and reasonableness of the possibility of such indefinite detention under the IRPA was subsequently challenged in Charkaoui $v$ Canada ${ }^{177}$ There the Supreme Court of Canada held that the absence of any detention review for foreign nationals until after the security certificate was reviewed by the Federal Court constituted a violation of the constitutional right against arbitrary detention under section 9 of the Charter of Rights and Freedoms. ${ }^{178}$ In October 2007, the Canadian government responded to the decision of the Supreme Court in Charkaoui by introducing Bill C-3, which amended the IPRA by adding provisions relating to special advocates. However the Bill made no reference to the legality of deporting non-citizens to countries where they face the possibility of torture. The Bill did, however, extend the requirement of a detention review to foreign nationals as well as permanent residents. ${ }^{179}$

\footnotetext{
${ }^{174}$ See Jennifer Tooze, 'Deportation with Assurances: The Approach of the UK courts' (2010) April Public Law 362. At the time of writing the UK has signed memoranda of understanding with Jordan, Lebanon, Libya and Ethiopia and has a framework agreement for obtaining assurances from Algeria.

${ }^{175}$ A v Secretary of State for the Home Department [2005] 2 AC 68 (HL).

${ }^{176}$ Ibid [81].

${ }^{177}$ Charkaoui v Canada (Citizenship and Immigration) [2007] 1 SCR 350.

178 Ibid [94]. Section 9 of the Charter protects an individual's civil liberties and human rights by safeguarding the right of persons not to be arbitrarily detained or imprisoned.

${ }^{179}$ Kent Roach, 'The Role and Capacities of Courts and Legislatures in Reviewing Canada's Anti-Terrorism Law' (2008) 24 Windsor Review of Legal and Social Issues 5, 48, and Macklin, above n 160, 8.
} 


\section{Deportation and the Threat of Torture: Challenges to the Canadian Security Certificate Regime}

The possibility of foreign nationals subjected to deportation under the IRPA facing torture and other maltreatment in their countries of origin raises legal questions regarding the possibility of a contravention of article 3 of the $U N$ Convention against Torture, ${ }^{180}$ as well as the Canadian Charter of Rights and Freedoms. ${ }^{181}$ The two cases of Suresh $v$ Canada ${ }^{182}$ and Ahani $v$ Canada ${ }^{183}$ concerned individuals affected by security certificates and whose possible expulsion from Canada would put them at a substantial risk of torture by their respective governments. They argued that their expulsion would breach article 3 of the UN Convention against Torture. ${ }^{184}$

In Suresh, it was alleged that the appellant was a member of and fundraiser for a proscribed terrorist organisation ${ }^{185}$ and consequently a security certificate was issued, with the appellant therefore facing the prospect of deportation. ${ }^{186}$ The Supreme Court of Canada held that, while it did not exclude the possibility that in 'exceptional circumstances' deportation to face torture might be justified under section 7 of the Canadian Charter of Rights and Freedoms, ${ }^{187}$ it is generally held that foreign nationals should not be deported when there is a substantial risk of torture. ${ }^{188}$ The Court stated that it was not directly constrained by article 3 of the UN Convention, but the 'fundamental justice balance under section 7 of the Charter of Rights and Freedoms generally precludes deportation to torture when applied on a case

180 Convention against Torture and Other Cruel, Inhuman or Degrading Treatment or Punishment, opened for signature 10 December 1984, 1465 UNTS 85 (entered into force 26 June 1987). Canada became party to the Convention in 1976.

${ }^{181}$ Canada Act 1982 (UK) c 11, sch B pt I ('Canadian Charter of Rights and Freedoms').

${ }^{182}$ Suresh v Canada (Citizenship and Immigration) [2002] 1 SCR 3.

${ }^{183}$ Ahani $v$ Canada (Citizenship and Immigration) [2002] 1 SCR 72.

${ }^{184}$ Article 3(1) of the UN Convention against Torture and Other Cruel, Inhuman or Degrading Treatment or Punishment states that 'No State Party shall expel, return ('refouler') or extradite a person to another State where there are substantial grounds for believing that he would be in danger of being subject to torture'.

185 The group was the Liberation Tigers of Tamil Eelam (LTTE) which is a terrorist organisation proscribed by Canada and many other states.

${ }^{186}$ Suresh v Canada (Citizenship and Immigration) [2002] 1 SCR 3, [1]. The appellant Suresh came to Canada from Sri Lanka in 1990. He was recognised as a Convention refugee in 1991 and applied for full immigration status, until the government detained him in 1995 and started proceedings to deport him.

${ }^{187}$ The Canadian Charter of Rights and Freedoms s 7, states that 'everyone has the right to life, liberty and security of the person and the right not to be deprived thereof except in accordance with the principles of fundamental justice'.

${ }^{188}$ Suresh v Canada (Citizenship and Immigration) [2002] 1 SCR 3, [78]. 
by case basis' ${ }^{189}$ The Supreme Court reaffirmed this view in its decision in the case of Ahani, and held that the findings in Suresh in respect to the prohibition to deport in cases of the possibility of torture should be followed. ${ }^{190}$ Despite this confirmation, the court dismissed the case of Ahani on the grounds that Ahani did not face a substantial and realistic risk of torture in Iran due his personal affiliation to the regime in Tehran. ${ }^{191}$

This decision in Ahani seems to overlook the fact that Canada is party to the UN Torture Convention, and also appears to contradict the continental view and position of the UK as highlighted by the ECtHR in the case of Chahal $v$ UK discussed above. Despite its regional character, the ECHR does indeed reiterate the binding international character of the prohibition of the use of torture as a jus cogens prohibition of international law. It seems that the Canadian government is aware of its legally doubtful position as evidenced by it having chosen to invoke 'exceptional circumstances' in each security certificate case where the opportunity has arisen ${ }^{192}$ in order to justify a possible derogation from its state obligations under international law.

The current measures taken by Canada in her attempt to prevent foreign nationals from becoming a terrorist threat to the nation are, as demonstrated, more radical, or even draconian, than those adopted by the UK and Australia. The UK has addressed the threat of future terrorist attacks through the enactment of control orders and assurance arrangements (DWAs) with several countries. Undoubtedly, the Canadian security certificate regime would not be acceptable in the UK, which has moved away from the previous detention without trial regime, implemented under the ATCSA. The UK's new control order regime appears certainly preferable to the security certificate system of Canada thanks to its apparent compliance with international human rights law.

\footnotetext{
${ }^{189}$ Ibid.

${ }^{190}$ Ahani $v$ Canada (Citizenship and Immigration) [2002] 1 SCR 72, [3]. The appellant Ahani was an Iranian citizen who had entered Canada in 1991 and claimed refugee status. The Canadian government named him on a security certificate as they suspected him of being a member of the Iranian Secret Intelligence, which the government alleged was a terrorist organisation.

${ }^{191}$ Ibid [26].

${ }^{192}$ Macklin, above n 160, 4.
} 


\section{The Future of Control ORders: Proposed Reforms AND ALTERNATIVE MEASURES}

Control orders have now been in existence for five years and seem set to remain in force for the foreseeable future, despite the legal challenges and media scrutiny. The UK's new coalition government, which came into power on 12 May 2010, has ordered a review of the current control order regime, a review which formed part of their manifesto pledge to the electorate. ${ }^{93}$ Prior to the 2010 election the Liberal Democrats wanted control orders to be completely scrapped whereas the Conservatives only wanted a review, and have consistently abstained from voting against control orders in Parliament. ${ }^{194}$ Nevertheless, senior representatives from both parties have called control orders 'illiberal', ${ }^{195}$ 'inherently objectionable' and 'illconceived'. ${ }^{196}$ Against this background of earlier dissent, we will now briefly reflect on proposed reforms for control orders and/or alternative measures that could be implemented.

The future of control orders and proposed reforms must be informed by the current high national security threat that terrorism continues to pose to the UK, a situation which is unlikely to change for the foreseeable future. Indeed it may even be fuelled by the ongoing military engagements arising out of what was once labelled the 'war on terror' by the United States of America and its allies. The British government's official response to this threat is centred on 'prevention' ${ }^{197}$ "which is reflected in its 'counter strategy to the threat of terrorism' or 'CONTEST'. The aim of the strategy - 'Pursue, Prevent, Protect, Prepare ${ }^{198}$ - is 'to reduce the risk to the UK and its interests

${ }^{193}$ Sam Coates et al, Coalition Reveals Populist Side with a 'Manifesto' of Compromise (21 May 2010) The Times <http://www.timesonline.co.uk/tol/news/politics/article 7132464.ece>.

194 Liberty press release, May 18, 2010, <http://www.liberty-human-rights.org.uk/media/ press/2010/terror-case-poses-first-test-to-new-coalition-on-rights-and-freedoms.php>.

195 BBC News, Review of control orders sought (16 September 2009) <http://news.bbc.co.uk/1/hi/uk/8258644.stm> and BBC News, 'Counter-terrorism powers to face government review' (13 July 2010) <http://www.bbc.co.uk/news/10619419>.

196 Patrick Sawer, One in Six Terror Suspects Flee Control Orders (22 May 2010)

Telegraph.co.uk <http://www.telegraph.co.uk/news/uknews/terrorism-in-the-uk/7753357/ One-in-six-terror-suspects-flee-control-orders.html>.

197 Clive Walker, 'The Threat of Terrorism and the Fate of Control Orders' (2010) January Public Law 4.

${ }^{198}$ Home Office, above n 5, 4. 
overseas from international terrorism, so that people can go about their lives freely and with confidence'. ${ }^{199}$

\section{A An Alternative Approach I: Travel Restriction Orders}

Lord Carlile, in his latest report on control orders, ${ }^{200}$ has suggested the possibility of Travel Restriction Orders (TROs) as a substitute and replacement for 'light touch' control orders, which are those considered to place lesser restrictions upon the individual. ${ }^{201}$ The main purpose of the TROs would be to restrain an individual, who appears not to have participated in any other terrorist acts or planning, from leaving the United Kingdom to train as a terrorist or otherwise participate in terrorist attacks outside the UK. ${ }^{202}$ The TROs would be intended for individuals who had become radicalised, and whose first and early intentions are manifested by the desire to go for training and/or act as an insurgent. ${ }^{203}$ A similar concept to the TROs, namely that of 'foreign restriction orders', is provided for under section 58 of the Counter Terrorism Act 2008. ${ }^{204}$ However, these measures can only be imposed on an individual upon their actual conviction for a terrorism offence. TROs would apply in the absence of conviction for a terrorist offence, and will offer 'proportionate protection in relation to a demonstrable intelligence-based risk assessment' ${ }^{205}$

The outline of the proposed TROs is akin to the outline of the control order system. They would be issued by the Home Secretary and last for up to a year at a time. ${ }^{206}$ An objective test would be set out whereby the Home Secretary would have to be satisfied that there is reasonable suspicion of an intention to act and he or she would need to consider the TRO necessary to protect others from the risk of terrorism. ${ }^{207} \mathrm{~A}$ limited range of restrictions would then be

\footnotetext{
${ }^{199}$ Ibid.

${ }^{200}$ Carlile, above n 132.

${ }^{201}$ Ibid [87].

202 Ibid.

${ }^{203}$ Ibid.

204 The Counter Terrorism Act 2008 (UK) c 28, s 58 states that Schedule 5 of the Act makes provisions for foreign travel restriction orders prohibiting persons from (a) travelling to a country outside the UK named or described in the order; (b) travelling to any country outside the UK other than a country named or described in the order; or (c) travelling to any country outside the UK.

${ }^{205}$ Carlile, above n 132, [87].

${ }^{206}$ Ibid [88].

${ }^{207}$ Ibid.
} 
available to place upon the individual concerned. ${ }^{208}$ It would be possible for the TRO to prohibit travel entirely or travel to certain designated countries. As with control orders, a breach of a TRO would result in mandatory criminal prosecution ${ }^{209}$ with only limited right to appeal. ${ }^{210}$

Whether TROs could constitute a real alternative to control orders remains to be seen. It seems as if the scope of restrictions available under both orders is identical. The current restrictions available under the control order system allow for a suspect to be restricted from leaving the UK, and subjected to all the conditions that the suggested TROs could impose. ${ }^{211}$ The suggested outline and application of the new TROs indicate that they are just the existing control order regime renamed in order to change public perception.

The overall usefulness of TROs in curbing the threat of 'home grown terrorists' is questionable. Jihadist training manuals and detailed instructions for bomb making are readily available on the internet. The July 7 bombers actually prepared for their attacks while in the UK. ${ }^{212}$ The identification of possible 'travel' candidates before subjecting them to TROs may, however, be useful to intelligence agencies, as the profiling of behavioural patterns of terrorist suspects has helped to disrupt other terrorist cells prior to and since July $7 .{ }^{213}$

The previous Labour government said that it would look into the recommendation of TROs further, but has highlighted similar criticisms to those outlined here, in its response to Lord Carlile's proposals. ${ }^{214}$ It is

\footnotetext{
${ }^{208}$ Ibid [89]. The conditions that could be imposed are: (a) the wearing of an electronic tag; (b) daily telephone reporting to the tag operating company; (c) notification of the person's home address to the police; (d) notification of the person's employment address to the police; (e) not entering any airport, seaport train or bus station providing direct travel links outside the UK without the consent of the Secretary of State; (f) the surrender of travel documents; (g) not applying for or being in possession of travel documents; and (h) not travelling outside the UK. ${ }^{209}$ Ibid [92].

${ }^{210}$ Ibid [93]. There is a right of appeal to a High Court judge with permission of the Court of Appeal.

211 The Prevention of Terrorism Act 2005 (UK) c 2, s 1(4)(i) can place a requirement on an individual subject to a control order to surrender a passport or other documents.

${ }^{212}$ Home Office, Report of the Official Account of the Bombings in London on $7^{\text {th }}$ July 2005, House of Commons Paper No 1087, Session 2005-06 (2006) [29].

${ }^{213}$ Ibid.

${ }^{214}$ Home Office, Fifth report of the Independent Reviewer pursuant to Section 14(3) of the Prevention of Terrorism Act 2005: The Government Reply to the Report by Lord Carlile of Berriew Q.C., Cm 7855 (2010) 4.
} 
unknown at present how the current Tory-Liberal government will consider the recommendation of TROs in its review of the control order regime.

\section{B An Alternative Approach II: Civil Contingencies Act 2004}

An alternative, more drastic, approach to control orders would be the invocation of emergency powers under Part II of the Civil Contingencies Act 2004 (CCA). ${ }^{215}$ This would allow legislation to be passed providing for detention without trial in times of an acute emergency if certain conditions listed in section 21 - were met. Such conditions are: that an emergency has occurred, is occurring or is about to occur (section 21(2)); that it is necessary to make provision for the purpose of preventing, controlling or mitigating an aspect or effect of the emergency (section 21(3); and that the need for the provision referred to in subsection (3) is urgent (section 21(4). ${ }^{216}$ The Act expressly refers to terrorism in its definition of an 'emergency' under section 19(1)(c). Use of the CCA in these circumstances could be seen as a legal safeguard for suspects as its emergency powers are strictly limited in their scope and duration. ${ }^{217}$ Consequently, this could lead to improved civil liberties protection for individuals. The human rights pressure group Liberty appears to favour the CCA as the preferred basis for detention without trial under emergency conditions: ${ }^{218}$

Emergency measures in the Civil Contingencies Act 2004 could already be triggered in a genuine emergency in which the police are overwhelmed by multiple terror plots, allowing the government to temporarily extend precharge detention subject to Parliamentary and judicial oversight. Safeguards offered by government today offer far less protection than that offered in the Civil Contingencies Act. ${ }^{219}$

Liberty perceives the selective use of emergency powers under the CCA as a balance between the civil liberties of an individual and the threat that terrorism poses to national security.

\footnotetext{
${ }^{215}$ Civil Contingencies Act 2004 (UK) c 36, s 20. Cf. D Campbell, 'The Threat of Terror and the Plausibility of Positivism' (2009) July Public Law 501. See also Walker, above n 197, 12.

${ }^{216}$ Home Office, Pre-charge Detention of Terrorist Suspects (Home Office, 2007) 7.

${ }^{217}$ Walker, above $\mathrm{n} 197,12$. Under s 26(1) an emergency regulation is limited to a maximum period of 30 days.

218 Shami Chakrabarti, So Much for Habeas Corpus (24 January 2008) Guardian.co.uk <http://www.guardian.co.uk/commentisfree/2008/jan/24/somuchforhabeascorpus>.

219 Liberty press release, April 24, 2008, <http://www.liberty-humanrights.org.uk/media/press/2008/liberty-director-shami-chakrabarti-tells-mps-54-public-

believe-government.php>
} 
This view, however, seems to overlook the considerable difficulties in directly applying the provisions of the CCA to individuals. The emergency powers provided for under the CCA are clearly designed to apply to the whole of the UK, or to specific regions, which are affected by a situation requiring the use of such powers. In Lord Carlile's opinion, a significant problem in using the CCA to detain or restrict terrorist suspects, is that the Act does not allow emergency legislation to affect criminal proceedings. ${ }^{220}$ The Act also does not expressly allow for the detention of individuals, ${ }^{221}$ despite the wide scope of section 22(3). ${ }^{222}$ In conclusion, one can only warn against the all too eager application of emergency regulations in times of a continuing terrorist threat, which would undoubtedly affect the scope of our civil liberties in general and accountability for them. ${ }^{223}$

\section{An Alternative Approach III: The Use of Intercept Evidence in Criminal Prosecution}

The Labour government stated that prosecution is always the preferred approach for dealing with terrorist suspects, and control orders are used only when prosecution or deportation is not possible. ${ }^{224}$ There is a suggestion by whom that the prosecution of terrorist suspects, who are otherwise subject to control orders, could be significantly increased if intercept evidence were admissible in court. Currently section 17 of the Regulation of Investigatory Powers Act 2000 (RIPA) excludes evidence in connection with any legal proceedings which discloses the contents of an intercepted communication or related communications data. This is in contrast to the position in Australia which has no such restrictions on the use of intercept evidence, ${ }^{225}$ providing that the interception has been lawfully carried out. ${ }^{226}$

In 2008, Sir John Chilcot chaired a Privy Council review to advise the government on the possibility of using intercepted material as evidence in court. ${ }^{227}$ The review considered the benefits which would be expected to result from the use of intercept evidence, in addition to the risks and the

\footnotetext{
${ }^{220}$ Ibid. Under the Civil Contingencies Act 2004 (UK) c 36, s 23(4)(d) emergency regulation must not alter procedure in relation to criminal proceedings.

${ }^{221}$ Ibid.

${ }^{222}$ Walker, above n 197, 13.

${ }^{223}$ Ibid; and Carlile, above n 132, [75].

${ }^{224}$ Joint Committee on Human Rights, above n 81, 6.

${ }^{225}$ Jaggers, above n 133, 11.

${ }^{226}$ Telecommunications (Interception and Access) Act 1979 (Cth).

${ }^{227}$ Privy Council Review, Privy Council Review of Intercept as Evidence: Report to the Prime Minister and the Home Secretary, Cm 7324 (2008) [1].
} 
envisaged resource implications of any changes in the law. ${ }^{228}$ It concluded that a means of using intercept evidence should be introduced into UK law 'by developing a robust legal model based in statute and compatible with the ECHR, ${ }^{229}$ provided that the use of the intercept material met certain operational requirements and was in toto ECHR-compatible. ${ }^{230}$ Serious doubts in regard to ensuring fairness in court remained ${ }^{231}$ and were confirmed in a recent ruling of the ECtHR in the case of Natunen $v$ Finland. ${ }^{232}$

However, a possible redrafting of section 17 RIPA has gained much support from several quarters of the government, with the Home Affairs Committee strongly recommending an immediate introduction of legislation allowing the use of intercept evidence in court. ${ }^{233}$ The Committee maintains its view expressed in 2007 that it is 'ridiculous that our prosecutors are denied the use of ... evidence that has been proved helpful in many other jurisdictions'. ${ }^{234}$ The former Director of Public Prosecutions (DPP), Sir Ken Macdonald, supported the opinion of the Home Affairs Committee by asserting that, if the UK had intercept evidence as an evidential tool, it would almost certainly 'mirror the experience of other jurisdictions where it is used frequently to great effect and results in the saving of considerable expense'. ${ }^{235}$

Lord Carlile has, however, stated that it is unlikely that the admissibility of intercept evidence would have led to the prosecution of any of the controlees since the control orders regime was introduced in $2005 .{ }^{236}$ His statement is supported by a review of nine current or former control order cases, which concluded that intercept evidence would not have enabled a criminal prosecution to be brought in any of the cases studied. ${ }^{237}$ Comparisons with other jurisdictions were rejected as 'ill-informed and misleading' ${ }^{238}$ In the

\footnotetext{
${ }^{228}$ Ibid [2].

${ }^{229}$ Ibid [216].

${ }^{230}$ Ibid [204].

${ }^{231}$ Home Office, Intercept as Evidence: A Report, Cm 7760 (2009) [10].

${ }^{232}$ Natunen v Finland (2009) 49 EHRR 32. The Strasbourg Court held that the appellants' art 6 rights had been infringed as a result of the prosecution not wholly disclosing the complete intercept evidence obtained to the court.

233 Home Affairs Committee, The Home Office's Response to Terrorist Attacks, House of Commons Paper No 117, Session 2009-10 (2010), [42].

234 Home Affairs Committee, The Government's Counter-Terrorism Proposals, House of Commons Paper No 43-I, Session 2007-08 (2007) [86].

235 Home Affairs Committee, above n 233, [35].

${ }^{236}$ Carlile, above n 132, [62].

237 A Johnson, Intercept as Evidence: A Report (2009, Cm 7760) [8].

${ }^{238}$ Carlile, above n 132, [59].
} 
UK's adversarial legal system the requirements for the disclosure of material to the defence are far more demanding in terms of parity and equality of arms than in the legal system of any comparable country. ${ }^{239}$

Due to this most recent rejection of the former government's proposed model for allowing intercept evidence to be used in court, it is clear that such evidence will not be admissible in terrorist trials for the foreseeable future. ${ }^{240}$ Even if intercept evidence were made available, in Lord Carlile's opinion this would not have helped to prosecute any of the 12 terrorist suspects who are subject to control orders at the present time. This warrants the question of what evidence the security services and police had on the 12 individuals that led them to believe they were a threat to national security and UK public.

\section{Possible Reforms of the Current Control Order System}

An important reform to the current control order system suggested by Lord Carlile and other commentators would be to impose a time limit of 12 months on control orders, without the option of renewal. ${ }^{241}$ Lord Carlile's reasoning was that, after a year of an individual being subject to a control order, the 'immediate utility of even a dedicated terrorist attack will have seriously been disrupted' ${ }^{242}$ This view was confirmed by the tribunal in the case of Secretary of State for the Home Department $v G G,{ }^{243}$ where it was stated that after ' 2 years an individual subject to a control order will have lost his usefulness to those engaged in terrorist activities'. ${ }^{444}$

Such a view on the 'arbitrary end date' for individual control orders ${ }^{245}$ was not shared by the last government, which stressed that the PTA provided effective checks and balances to ensure that the opportunity to renew a control order, if it is necessary, is lawful. ${ }^{246}$ The government argued that setting a definite end

\footnotetext{
239 Ibid.

${ }^{240}$ Ibid [58].

${ }^{241}$ Carlile, above n 41, [58] and Walker, above n 197, 16.

${ }^{242}$ Carlile, above $n$ 41, [58].

${ }^{243}$ Secretary of State for the Home Department v GG [2009] EWHC 142 (Admin) (12 February 2009).

${ }^{244}$ Ibid [23].

${ }^{245}$ Home Office, Fourth Report of the Independent Reviewer pursuant to Section 14(3) of the Prevention of Terrorism Act 2005: The Government Response to the Report by Lord Carlile of Berriew QC, Cm 7624 (2009) 9.

${ }^{246}$ Ibid. Section 2(6) PTA affords the Secretary of State power to renew a non-derogating control order only if he or she considers it necessary: (a) for purposes connected with
} 
date would allow individual terrorism suspects and controlees to simply disengage from involvement with terrorist-related activity, knowing that they could re-engage after the end of that time period. ${ }^{247}$

The impact of indefinite control orders on the lives of controlees can be quite significant. Without a definite time limit, individuals under a control order remain in a 'state of suspended investigation' year after year with only limited appeal possibilities - a situation to which criminal suspects are not subject. ${ }^{248}$ Presently, out of the 12 individuals subject to a control order, three have been subjected to the order for more than two years, with one of those controlees now in his fifth year. ${ }^{249}$ With control orders having no definite end date, an individual could be subject to one for an infinite period of time, with no realistic prospect of being either prosecuted or released - a truly Kafkaesque situation. ${ }^{250}$

It appears that control orders at present are used to 'plug the gap' in cases where neither prosecution nor deportation would work as security measures. Having assessed the reforms and alternative measures proposed by various commentators, one must conclude that control orders are here to stay. There are no clear alternatives which can effectively 'prevent' an individual from participating in terrorist related activity. The previous government maintained that abandoning the control order system entirely would have a serious damaging impact on national security, ${ }^{251}$ a view shared by Lord Carlile. ${ }^{252}$ However, it has yet to be seen whether the new Tory-Liberal government will adopt this view after it has undertaken a review of the control order regime one of its pledges to the electorate after coming into power.

A possible reform could be the introduction of a time limit of 12 months without further renewal options. This would result in greater civil liberties protection for the individual while helping to strike a balance between the liberty of an individual and the security of the nation.

\footnotetext{
protecting members of the public from the risk of terrorism; or (b) for the purposes connected with preventing or restricting involvement by that person in terrorism related activity.

247 Ibid.

${ }^{248}$ Walker, above n 197, 16.

${ }^{249}$ Carlile, above n 132, [43].

${ }^{250}$ Franz Kafka, The Trial (Penguin, 2000).

${ }^{251}$ Home Office, above n 245, 1.

${ }^{252}$ Carlile, above n 132, [85].
} 


\section{CONCLUSION}

Amidst the considerable controversy which has arisen since their implementation, control orders have now commenced their sixth year of operation. The essential question to ask, however, is whether they have been successful in 'preventing' the individuals subject to them from participating in terrorism related activity. The government has stated in the past that the control order regime has successfully protected the UK from a possible terrorist attack by preventing the individuals successfully from participating in any possible terrorist related activity. But this 'success' came at the cost of possible violation of these individuals' right to liberty, as granted under article 5 of the ECHR.

The UK is not alone in respect of such controversy. The Commonwealth jurisdictions of Canada and Australia faced massive criticism of their antiterrorism legislation. The constitutional validity of Australia's control order regime, which has been heavily influenced by the UK precedent, has been challenged. In Australia, by contrast with the UK, no jurisprudence exists on the possible conflict between the right to liberty and the security of the nation. However, with Australia's likely adoption of a federal Charter of Rights, there remains a remote possibility that a civil liberties challenge to the country's control order regime could eventually arise. In Canada, however, cases have been decided concerning the country's security certificate regime. An apparent shortcoming of this regime lies in Canada's use of deportation measures against foreign nationals suspected of terrorism and of the possibility of the suspects' torture, if they are deported.

The present situation in the UK is that a curfew length of less than 16 hours will not constitute a deprivation of an individual's liberty. Nevertheless, the judiciary has shown that it will not hesitate to cancel any control order, as evidenced in the abovementioned cases of $J J$ and $A P$, which it considers an interference of an individual's article 5 rights. Currently the ECHR ruling in Guzzardi, ${ }^{253}$ suggests that, for control orders, the threshold for a deprivation of liberty within the meaning of article 5 is set at a very high level. Until a

${ }^{253}$ Guzzardi v Italy (1980) 39 Eur Court HR (ser A). The most recent ECtHR case in the context of ATL concerns the above case of $A$, see $A v$ United Kingdom (European Court of Human Rights, Grand Chamber, Application No 3455/05, 19 February 2009), 188 confirming the House of Lords' 2004 decision. 
control order case concerning article 5 reaches the ECtHR in Strasbourg, the government will continue to use such orders. ${ }^{254}$

Today, control orders may constitute the most effective means of 'preventing' individuals from participating in terrorist related activity. The alternative measures which have been identified by various commentators do not stand up to scrutiny in terms of effectiveness. However, one reform that should be adopted by the government is a time limit of 12 months without a further renewal period. In other words, if the individual subject to a control order has not been prosecuted within 12 months of receiving the order, then there should be no option for a renewal. This would strike a fairer balance between an individual's fundamental right to liberty and the right of the government to protect its citizens from the threat of terrorism.

Until the terrorist threat which the UK faces diminishes, or an alternative method is suggested that has not already been identified — which appears unlikely - control orders are likely to remain. If they were abolished it would be necessary to release the 12 individuals subjected to control orders, a notion which the government will simply not accept, as it believes the 12 controlees to be a threat to the lives of its citizens, which it aims to protect.

Time will tell to what extent Realpolitik will dictate the future actions of the present UK coalition government and to what extent the underlying conflict between human rights and overall state security, as exemplified in Lord Hoffmann's stern warning quoted above, will be resolved. ${ }^{255}$

\footnotetext{
${ }^{254}$ In A v United Kingdom (European Court of Human Rights, Grand Chamber, Application No 3455/05, 19 February 2009) [188] the ECtHR noted the absence of discrimination based on nationality in the context of control orders.

${ }^{255}$ See BBC News, above $\mathrm{n} 195$, for an overview of the present government's announcements regarding possible changes to anti-terrorism legislation and Hoffmann, above n 2, for Lord Hoffmann's pronouncement.
} 